Volume: 6, Issue: 4/ December 2021

\title{
The Roles and Responsibilities of School \\ Administrators During the Emergency Remote \\ Teaching Process in Covid-19 Pandemic
}

\author{
Sadegül Akbaba Altun \\ Başkent University, Ankara, Turkey \\ Mustafa Bulut \\ Başkent University, Ankara, Turkey
}

\begin{tabular}{lr}
\hline Abstract & Article Info \\
\hline When Covid 19 pandemic started, schools in Turkey, as in many parts & $\begin{array}{r}\text { Article History: } \\
\text { Received }\end{array}$ \\
of the world, were closed and then emergency remote teaching started. & January 19, 2021 \\
The purpose of this study is to explain the roles and responsibilities of & Accepted \\
school administrators related to emergency remote teaching after & August 28, 2021 \\
schools were closed. In order to reveal the purpose above, this research & \\
was carried out in qualitative research design. 105 school & \\
administrators from different regions of Turkey and different school & \\
levels participated in the study. The data were collected through a & Keywords: \\
Google Drive form with open-ended questions. The collected data were & School \\
analyzed with content and descriptive analyses. The findings showed & Covid-19, \\
that the roles and responsibilities of the school administrators & adming reaching. \\
regarding emergency remote teaching included planning the process, \\
starting online classes, opening different social media accounts, \\
managing the online program, solving the adaptation problems of \\
students and teachers, monitoring the actions taken and motivating \\
teachers, students, parents; communication and finally it has been seen \\
that they are in the act of transition to and maintaining digital \\
management. During the Covid 19 pandemic, school administrators \\
have mostly done "communication". There were also changes in the \\
communication styles of school administrators and social media tools \\
were used effectively. The intensive use of technology in this period has
\end{tabular}


caused changes in management processes and managers have mostly talked about digital management and the exhausting aspects of digital management are expressed as well as the facilitating ones. Since emergency remote teaching is not a common case in the K-12 Turkish education system, we hope the results of this study will contribute to a better understanding of the roles and responsibilities of school administrators during such emergency periods.

\section{Cite as:}

Akbaba-Altun, S. \& Bulut, M. (2021). The roles and responsibilities of school administrators during the emergency remote teaching process in Covid-19 pandemic. Research in Educational Administration $\mathcal{E} \quad$ Leadership, 6(4), 870-901. DOI: 10.30828/real/2021.4.4

\section{Introduction}

The Covid-19 outbreak emerged in Wuhan (Wuhan), China in December 2019 and unfortunately spread to the world from this city. Covid 19 cases were first seen on 11 March, 2020 in Turkey and on March 13, 2020 Higher Education Council (HEC) announced that education was interrupted for three weeks and at the end of this period, it would be carried out remotely (https://www.yok.gov.tr). Therefore, the rest of the 2019-2020 spring and the fall semester in higher education was online. The Ministry of National Education also closed all schools until the end of April 2020, and then education was conducted remotely by broadcasting over the Education Information Network (EBA) and TRT (Turkish Radio and Television Corporation). In the fall semester of 2020-2021, face to face education started with pre-school, 1st grade, 8 th and 12th grades and it was shared with the public that gradual transition for other levels would also be made. Education has been among the most affected sectors in the Covid 19 outbreak all over the world. According to UNESCO's May 2020 data, 
schools in 132 countries around the world have been mostly or partially closed, and 1,048,817,181 students around the world have been affected by this pandemic. 24,901,925 students in total were affected from preschool, primary education, secondary education and higher education in Turkey. During the pandemic period, serious problems, crises and chaos have been experienced at every level of education, and therefore the practices of school administrators have also been affected to a great extent as there was a quick shift from traditional modes of administration to a new process. The present study was designed to identify the roles and responsibilities of school administrators during such a new period. As emergency remote teaching is not a common initiative in educational systems, the roles and responsibilities of school administrators during this period have not been studied enough. We believe, the results of the study will necessitate the authorities to reconsider the in-service training programs of school administrators taking into consideration the experiences portrayed in the findings since the study has several implications for practice. To address above objectives, the study tries to answer the following research questions:

1. What did school administrators do just after the Covid-19 outbreak started?

2. How were their roles and responsibilities different from their routine practices?

\section{Literature Review}

There have always been serious pandemics in every period of history. Undoubtedly, this Covid 19 outbreak will not be the last. Therefore, human beings should be ready for such pandemics and the 
crises that they will create in future. Crisis can be defined as a situation that an unexpected condition makes or causes in the organizational environment, and if not managed well, it will often create negative results. Schools are places that are affected by such conditions. As a result, school administrators are responsible for the effective management of contingencies caused by the Covid 19 pandemic in schools and their behaviors during ordinary and extraordinary situations should be different (Akbaba-Altun, 2011; 2016). Likewise, their roles and responsibilities also differ from the routine in emergencies

As we all know, the main goal of education is student achievement, but that doesn't mean that students always need to be the focus of an administrator's efforts (Hoerr, 2009). They have many other responsibilities. Mishra and Yadav (2013) define school administrators as the kingpins of any institutions. They are the people who are responsible for the achievement of the goals of an institution, whether it is in the form of effective planning or the successful implementation or the development of a healthy organizational climate. They act as the change agent that transforms the teaching and learning culture of an institution. Muller and Hutingen (2008) add that school administrators are the ones who create conditions which foster teacher development and student learning. During ordinary times, when there is no extraordinary situations or happenings, the responsibilities of administrators cover the smooth and effective management and operation of a school and the development of the work and life in this school, in addition to the close observation of teachers' work. Besides, the administrator undertakes teaching responsibilities within the frame of the school programme and the curriculum and keeps and maintains the archives and the property of 
the school. In addition, administrators carry out any other responsibilities given for the interest of the students, of the school and of education in general (Hadjithoma-Garstka, 2011). Kwan (2011) lists similar roles and responsibilities as external communication and connection, attending meetings with government officials, quality assurance and accountability, undertaking evaluation activities for school-based curriculum projects, teaching, learning and curriculum, organising school-based curriculum development activities, staff management, orientation of staff, resource management, preparing the school budget, leader and teacher growth and development, planning training and development programmes for teachers, strategic direction and policy environment and formulating long-term school plans. Another function carried out by administrators is supervision (Blume, Diehl, Norton, Varner, \& Marshall, 1946). There are five main functions of school administrators as supervisors. These functions are leadership, co-ordination, personnel, research, and public relations (Kindred, 1951). School administrators are also multicultural leaders (Gardiner \& Enomoto, 2006) in many parts of the World, especially nowadays, and creators a safe school climate (Cisler \& Bruce, 2013). Finally, some other roles individually achieved by school administrators include creating, communicating, and boosting an evidence-based agenda and necessary work tasks (Cosner, 2011).

However, things sometimes become challenging for educational organizations, especially in hard times and crisis as we experience today. Several studies were carried out in the world (Grant \& Mack, 2004; Jimerson, Brock, \& Pletcher, 2005; Sandoval \& Brock, 2002) and in Turkey (Aksoy \& Aksoy, 2003; Aksöz, Erdur-Baker, \& Akbaba-Altun, 2008; Çiçek \& Özsezer, 2015; Döş \& Cömert, 2012) on what school administrators should do with regard to crisis 
management. Grant and Mack (2004) claim that crises are inevitable, organizations may face crises sooner or later, and they emphasize that the leaders of organizations have to react to the devastation and uncertainty and radical changes caused by crises. Sandoval and Brock (2002) who find it very important to study crisis situations in schools explain this by saying that schools are places where students and staff are concentrated and that busy places are more prone to chaos. A specific example comes from Turkey to illustrate school administrators' role and responsibilities during crises. In provinces where natural disasters are experienced in Turkey, crisis desks affiliated to governorships are established and solutions are produced for the disaster experienced here. In this process, school administrators, who are education leaders, take part in crisis desks at the provincial level during these crisis periods and try to continue their educational activities by solving problems both in their own schools and in other schools (Akbaba-Altun, 2011).

According to Sandoval and Brock (2002), children spend most of the day at school and may panic more quickly than adults. Therefore, prevention of crises is also important at this point. During crises at schools, the quantity and quality of the changes become so much that it might horrify school administrators and staff and they feel that they do not have the chance or ability to cope with the changes (Behbahani, 2011). Their relations with department heads, teachers, tighten to a great extent (Telem, 2001) during such times. Their tasks and duties become varied and complex. They do their best to form the link between the school, parents, the community, and the central educational bureaucracy. They supervise teachers, maintain facilities, secure and manage resources, try hard to solve conflicts, and supervise record keeping (Anderson, 2008). Because of such work diversity "they 
wear too many hats" (Spillane \& Lee, 2014). Their role extends to include that of entrepreneur, community organizer, and negotiator in addition to that of instructional and moral leader (White-Smith \& White, 2009). Thus, a "do as we all have done for years" philosophy to improve the schools doesn't catch most administrators' attention (Wegenke, 2000) in both ordinary and crisis periods. In a similar study; Reyes-Guerra, Maslin-Ostrowski, Barakat and Stefanovic (2021) stated that during the initial phase of the pandemic, school administrators became personalized and pragmatic communicators along with new priorities and led the staff with flexibility, creativity and care. Another study by Kaminskiene, Tütlys, Gedviliene and Chu (2021), about the practices of school principals in Lithuania, showed that they focused on staff training, technological preparation just after the outbreak of the pandemic, followed by student related work.

Apart from the ones listed above, another responsibility of administrators during crisis like the one we experience these days is online leadership. Online administrators increasingly need to be more innovative to help lead and guide this new expanding area. Online administrators cannot just want innovation from their teachers to meet changing student needs and different government accountabilities; they also need to lead the innovation. They also have to know about online learning, they have to be invested in online learning, and they have to help their teachers to adapt and change (Quilici \& Joki, 2011). Similarly, due to the new modes of teaching and administration that have been necessitated by the pandemic, one leadership role of school administrators today is the technological leadership (Akbaba-Altun, 2004; 2008). Such changes in school administrators' role, resulting from the computerization of instruction and administration occur in six major categories: these are accountability, instruction evaluation, 
supervision, feedback, frequency of meetings, and shared decision making (Telem, 2001). Also, changes in technology cause changes in organizational styles and methods and any change necessitates to change acquiring knowledge and skills (Behbahani, 2011). All in all, whether in everyday routines or challenging periods, the traditional role of administrators as managers is expanded to instructional leaders (Mestry, Moonsammy-Koopasammy, \& Schmidt, 2013). What is more, school leaders are expected to have clear and measurable goals for the achievement of the school as a whole, as well as for individual students, and they're expected to monitor data regarding the achievement of these goals (Marzano, 2013).

\section{Method}

\section{Research Design}

This study was designed as a qualitative case study. While Berg (1998) systematically defined a case study as a method that explains how the situation works by collecting information about the person, social environment, event, group about a special situation, Graham (2000) stated that the situation should be a human activity to be explained in its context. According to Yin (1994), there are three cases in which case study is preferred. These situations are:

1. When asked "how" and "why" questions

2. When the investigator has little control over the event or situation

3. When there is a real phenomenon in real life

While Stake (1995) defines cases as systems with definite boundaries, Elger (2010) claims that systems with demarcated borders can be considered as a research unit, and that this can be an individual, 
as well as an event or event in a situation, processes or organizations. In this research, the case was taken as the Covid 19 outbreak and the research focused on the rich descriptions of the actions and experiences of school administrators concerning emergency remote teaching during this pandemic.

\section{Sample}

105 school administrators from different education levels participated in the study. $73.3 \%$ of the participants are men and $26.7 \%$ are women. $4.7 \%$ of the participants work in preschool level, $36.2 \%$ in primary schools, $21 \%$ in secondary schools, $38.1 \%$ in high school level. Most of them (76.2\%) who take part in the research work as administrators. Considering the seniority of the participants in administration, $48.6 \%$ of the participants said that they worked as an administrator for $7-18$ years. $16.2 \%$ of the participants remarked they worked for 19-30 years. It can be said that the participants are experienced in school administration. While $40 \%$ of the participants are undergraduate, $56.2 \%$ have a master's degree.

\section{Data Collection and Analysis}

Data were collected using a Google Drive form because of pandemic constraints and therefore face to face interviews were almost impossible. School administrators have been invited to participate in this research through different social media accounts. The collected data was first prepared as a Word file and the answers were coded separately. The roles and responsibilities of school administrators were coded first and then divided into categories. The findings of the research have been reported by supporting with quotations. 


\section{Findings}

The answers given to the research questions are illustrated in Figure 1 below. The figure demonstrates that the school administrators were busy planning emergency remote teaching, starting online classes, opening different social media accounts, managing the online program, solving the adaptation problems of students and teachers, monitoring the actions taken and motivating teachers and students, parents, doing a lot of communication and finally transition to and maintaining digital management.

School administrators also expressed that they carried out continuous research about the remote teaching systems and informed teachers about this process, and they contacted students, parents and teachers and planned and implemented remote teaching in the best way. Opinions on this issue are given below:

"I constantly researched about the new system and kept informing my teachers."

"We launched the educational activities on our website at school."

"Obviously, that process is the right decision and guiding teachers to educational activities such as youtube, kahoot, zoom."

"I tried to communicate effectively with teachers and students about work related to remote teaching on alternating working days and other times."

"EBA (Education and Information Network) trainings, live lessons, informing my teachers and students about the process." 
Figure 1.

School administrators' roles and responsibilities during emergency remote teaching

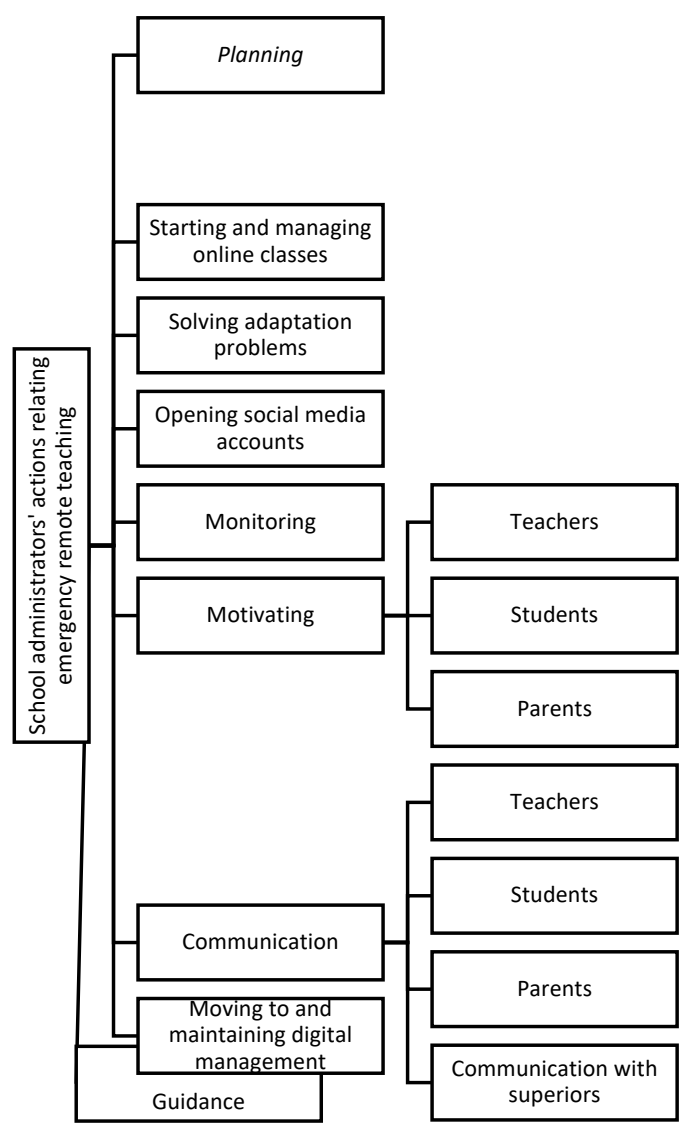

\section{Planning}

George (1972) puts forward the importance of planning saying that every kind of managerial act is unavoidably intertwined with planning. It is as much a part of every managerial process as breathing is to the living human being. School administrators participating in the study planned remote teaching during the Covid-19 period 
meticulously. They made plans for online exams, parents' meetings, determining and meeting the needs of students. Therefore, they attended the Ministry's seminars on planning emergency remote teaching and uttered their planning processes for it in the following statements:

"Designing the future education process by strategic planning"

"Planning - I planned online exams, parents' meetings etc."

"After planning, I had each student called and filled out a form. By calling the particular students to the guidance service and classroom teachers, we met their basic needs together and provided psychological support."

"Keeping in touch with our teachers and parents, we adapted our plans to homes for the children to have a heal thy time at home."

"We planned remote teaching studies. I participated in the remote inservice training activities organized by the Ministry of Education."

\section{Guidance}

Bortree (2010) defines guidance as advice, help, direction or support. People can give guidance others by offering counsel, developing guidelines, setting limits, assisting with decision making, providing information with the intent of aiding or acting as a reliable source for ideas. Providing effective and quick guidance and assistance in crisis situations is utmost important as people may not know what to do or how to behave. Thus, school administrators directed teachers to online trainings. School administrators also provided information and guidance to both students and teachers about remote teaching. The views of school administrators on these issues are given below. 
"I directed the teachers in my old and new schools and enthusiastic teachers that I know around me to online trainings and MEBBIS (Ministry of National Education Information Systems) remote teaching. I tried to keep my teachers active by monitoring EBA (Education and Information Network)"

"I interviewed all classes by connecting via Zoom; I tried to support the children and I informed and guided that the education and training process was not over and we would continue at home instead of school."

\section{Starting and Managing Online Classes}

As school closures occurred in Turkey and most of the world because of this severe pandemic, educational institutions moved from traditional face to face education to remote teaching via online classes and this shift seemed to be one the smartest ways of conducting education well. After school administrators received necessary trainings, they started to plan remote teaching and started the education process. The views of the managers on this issue are below:

"I prepared for the remote teaching process"

"Online studies and classes started"

"We started lessons via remote teaching with teachers"

"Education was done with remote teaching methods"

\section{Opening Social Media Accounts}

In this COVID-19 pandemic, social media has the potential, as long as it is responsibly and appropriately used, to provide rapid and effective dissemination routes for key information (Chan, Nickson, 
Rudolph, Lee, \& Joynt, 2020). As a result, after the school administrators started remote teaching, they opened different social media accounts and increased the number of live lessons in order to access and inform students through different channels. One school administrator remarked:

"During this period, we opened a Youtube channel on behalf of our school and uploaded the videos there. We prepared Google Forms and asked teachers every week for information about the students they reached. We created an EBA live course group on WhatsApp and made live course programs and they still continue."

\section{Solving the Adaptation Problems}

Adaptation is usually described as the adjustment that are necessary for new circumstances. Due to Covid-19 pandemic; several emotional, social, environmental and physical adaptations were immediately necessary. After school administrators started remote teaching, they supported teachers and students who had difficulties adapting to the process. The opinion of a school administrator on this issue is below:

"We tried to make up for the process with remote teaching lessons. But it is certain that there is a group of students and teachers who have problems adapting to the process."

\section{Monitoring}

School administrators said that they also monitored how remote teaching was carried out saying, "I made a special effort for the active use of EBA", "I did an organization to monitor remote teaching and student studies", "I watched the process on Zoom and Youtube". 


\section{Motivation}

Motivation is described as a process in which an activity is initiated and continued for a purpose (Pintrich \& Schunk, 2002). The Covid 19 process has affected school administrators as well as everyone else deeply. While some school administrators explained that their motivation decreased in this period, some of them reported that they tried to motivate both themselves, teachers, students and parents.

\section{Motivating teachers}

The strategies that school administrators used to keep motivation high are to try to look competent, to make attentive sentences with teachers to keep their motivation high, to frequently call and ask about the situation, to share messages that will increase their morale, and to have in person interviews especially with teachers who had low motivation for remote teaching.

"... However, I tried to appear skillful in order to keep myself and my employees motivated."

"From the first week, I tried to keep our teachers motivated by holding online meetings."

"I was careful to make sentences that would keep the motivation of teachers, students and employees high. I talked privately with teachers who were reluctant about remote teaching."

"First of all, I shared messages that would increase morale and motivation of my teachers."

"I often called the teachers and asked after them." 


\section{Motivating Students and Parents}

School administrators have tried to motivate students not to leave the lesson in this period. The views of two school administrators on this issue are below:

"With emergency remote teaching, we try hard to ensure that students do not break away from classes."

"For example, I promised a gift to the student who read $x$ book from EBA or gave the first correct answer to the question I asked."

School administrators also tried to motivate students and parents in this process. School administrators remarked in the following statements that they wrote letters to students and especially they asked teachers to motivate parents and students.

"I tried to direct the emergency remote teaching process by stating that they should be with our students and parents by making individual phone calls, so that we would feel happy and that being in contact with children would also contribute to the children."

"I wrote letters to the students."

\section{Communication}

Communication is the process of exchanging meaning and messages between individuals using a shared system of symbols. Communication was the most common thing school administrators did during the Covid 19 outbreak since the pandemic demands strengthening the personal relevance of effective communications (Reddy \& Gupta, 2020). They have been in contact with teachers, 
students, parents, superiors and different segments of society through different communication tools during this period.

"Remote communication sources were specified and implemented"

"I talked to our teachers and some parents every day. I explained that we needed to reach our students and parents through Zoom, EBA and Whatsapp"

"I have always done my best to be in contact with teachers, students and parents."

"I continued my communication with teachers, students and their parents through communication channels."

\section{Communication with Parents}

School administrators supported parents by calling them or holding online meetings and shared the Ministerial decisions with them instantly. Managerial views on this issue are below.

"I called the parents. I had a parents' meeting."

“--- We supported our parents and students .."

"The decisions of the Ministry and Governorship were shared instantly with parent communication groups. Education support programs were shared with them."

\section{Communication with Students}

School administrators have similarly motivated both themselves and teachers and reached out to students and tried to support them. To communicate effectively, they held meetings with 
them via text messages or social media tools. Managerial views on this issue are below:

"--- but since the technological possibilities are different, I tried to make our teachers touch the students by using social media."

"We increased communication with our teachers and motivated our children. We made live connections."

"We made plans to keep calling our students."

"By exhibiting a lot of social and course content works on common platforms, I mobilized other teachers and increased the motivation of the students."

"I held motivational meetings for all students with online programs."

“... conferences ... communications with students ...

"Continuous communication with students via text messages and social media."

\section{Communication with Teachers}

The other group that school administrators were in constant contact with during the Covid 19 outbreak were teachers. The administrators described their communication with teachers during this period as "We communicated with teachers frequently in this period."

\section{Communication with Superiors}

Another group that school administrators were in contact with during the Covid 19 outbreak were their superiors. They both shared 
their thoughts with their superiors and they also followed orders from them. "I shared my thoughts with the general directorate to which I am affiliated. I investigated the measures taken by the world and their applicability in our country, in my school", "I took the actions that were told me by the higher authorities".

\section{Transition to and Maintaining Digital Management.}

Digital management is described as the change in the way management is carried out in an organization as a result of digital transformation. In other words, it is the usage of the Internet in administrative tasks and duties so as to improve effectiveness and productivity. School administrators said that they developed such digital management during the Covid 19 pandemic. While some of the school administrators claimed it was more difficult and tiring to manage this process remotely, a school administrator told us they understood that face-to-face management and meetings had cost them a lot of time.

"We developed digital management skills due to the work in the digital platform."

"It is more difficult to manage the process remotely. I felt more mental fatigue than normal even when working from home."

"It is more tiring because you always have to manage someone from distance: a teacher, parent, student.

"Then I studied the EBA in depth. I saw that instead of maintenance and repairs etc. I led the educational process for 1.5 months. I understood that how nonsense were unnecessary and time-consuming negotiations." 


\section{Conclusions and Discussion}

Today, most scientists and researchers of education believe that if we are to have a change in education, it should be started from educational management (Behbahani, 2011). As a result, school administrators as the representatives of educational management in schools are of great importance. They have various roles and responsibilities. First of all, they are to shape the school's culture to focus unceasing attention on student learning (Louis \& Walstrom, 2011). They also construct meaning about their own leadership development and ability to enable effective school change by connecting their knowledge and understanding of what leadership requires and how it is shared with others (Larsen \& Reickhoff, 2014). Also, administrators as school leaders make sense of and eventually add meaning to stakeholder actions within their schools, school systems, and communities (Wegenke, 2000). Administrators that are efficient in generating emotional attachment with their staff through listening, trust, encouragement etc. are likely to harness the staff to follow their vision or policy. In addition, administrators need to be aware of the effect of their emotion displays and management on teachers who are likely to go beyond formal role expectations and start new projects and teaching methods at work (Oplatka, 2013). What is more, retaining and developing quality teachers is their other priority. School administrators have to work with the staff to develop a community of learners working towards common goals and make decisions based on shared experiences and results (Watkins, 2005). Promoting teacher professional development and encouraging innovative or risk-taking activities is linked to the extent to which an educational reform is likely to be present in a school (Kadji-Beltran, Zachariou, \& Stevenson, 2013). 
It is widely known that school administrators have a heavy workload and that it has still been increasing recently (Lindberg, 2012) due to unexpected situations caused by the pandemic. Nowadays, administrators in schools help in improving job satisfaction teachers, establishing firm links with parents of students, strengthen associations, lower educational loss, improvement in renovation and creativity in benefiting from human resources and facilities and ultimately, improve the quality of children and juveniles' lives (Behbahani, 2011). Because, initially resisted, online education has become a part of life for both families and students, and the perspectives have changed. After this pandemic, new approaches and new tools will certainly be developed in online, blended education and even face-to-face education.

In the study, school administrators stated that with the closing of the schools, they prepared their schools for emergency remote teaching, they constantly researched on it and informed teachers about this process. In addition, they contacted students, parents and teachers and planned and implemented remote teaching in the best way. School administrators participating in the research are usually in the action of planning remote teaching, directing teachers about it, starting online lessons, opening different social media accounts, managing the online program, solving the adaptation problems of students and teachers, monitoring the actions taken and motivating teachers and students and parents. The management processes of school administrators have been transitioning to digital management and maintaining it. It was concluded that the traditional roles and responsibilities of school administrators changed shape in terms of content. In particular, crisis management, the need for more motivation, psychological support, and transition to digital management, are specific to the process. 
School administrators used the concept of transition to digital management for the first time and mentioned the advantages and disadvantages of this. Digital management will be at the top of the concepts created by the Covid 19 process and that will be heard in management. During the Covid 19 pandemic, the most common work done by school administrators was communication. They have been in contact with teachers, students, parents, superiors and different segments of society through different communication tools during this period. There have also been changes in the communication styles of school administrators. The most important of these changes are the effective use of social media tools and organizing online meetings with parents, teachers and students through these social media tools. The existence of technology has caused changes in management processes. Covid 19 pandemic has resulted in taking advantage of these technologies quickly and utilizing them in management processes effectively in Turkey.

Also, communication has gained importance in digital management. Because social media tools provide the opportunity to reach many people in a short time. Hayashi and Soo (2012) also suggest using social media tools in crisis and disaster situations. However, effective communication is related to the ownership of communication tools by all stakeholders and their effective use. In digital online management, the control area has expanded, online monitoring, supervision, and online meetings have been held. The exhausting aspects of digital management are expressed as well as the facilitating ones. Since the concept of time has disappeared, the opportunity to meet at every hour has created digital fatigue that has increased both convenience and workload. Being at home brought along role confusion. 
As each crisis causes new opportunities and changes, the Covid 19 pandemic has also led to significant changes management processes. They have started to take place online and with certain tools. School administrators made mass communication by sending messages to thousands of students and interacted with smaller groups or individually in a short time.

The present study, though with some limitations as it only covers some administrators' experiences and practices during the pandemic, tried to depict a portrait of what was going on at schools in terms of administrative roles and responsibilities. The findings above reminded us again that leadership, especially educational leadership roles of administrators are of utmost importance during such hard times.

Canese and Amarilla (2020) state in their study that in spite of the difficulties, this Covid-19 outbreak is a great opportunity to rethink the educational system. Accordingly, the present study also draws out some policy, practice and research implications to be considered again in terms of school administrators, for both during and post pandemic periods. First of all, effective and high quality in-service training programs and seminars particularly on leadership and crisis management should be envisaged for administrators in order that they can easily cope with unexpected situations and difficulties as this pandemic is definitely not the last one. For other trainings and seminars, needs and skills analyses should be done for a comprehensive view. In addition to in-service training programs for administrators, policy responses should be reconsidered. Since the pandemic started, policy responses have mostly covered online educational tools, preparation of online materials, psychosocial support, free Internet access (Özer, 2020); resolving digital equities, 
digital pedagogy, student training (Greenhow, Lewin, \& Staudt Willet, 2021); promoting the development of teaching, transformation of education paradigm, disadvantaged students (Xue, Li, Li, \& Shang, 2021), inequities (Kidson, Lipscombe, \& Tindall-Ford, 2020); teacher training and teaching improvement (Quezada, Talbot, \& QuezadaParker, 2020). However, governments along with educational policy makers also need to maintain a sharp focus on highly critical and new roles and responsibilities of administrators who are providing significant and to the point educational continuity. Because concurrently supporting students and teachers is really demanding for administrators during such challenging times. As for research on administrators, the subject matters and issues so far have been related to needs for assistance concerning student support, access to digital materials, guidance for working online (Johnson, Veletsianos, \& Seaman, 2020); leadership (Francisco \& Nuqui, 2020); positive and negative aspects of the pandemic, Internet access, technical infrastructure, computer/tablet shortages, problems during the pandemic (Zincirli, 2021); decision making experiences (Kells, 2021); and how to spearhead the continuity of teaching and learning during the pandemic (Asio \& Bayucca, 2021). Yet, with the continuing presence of this severe pandemic, we need in-depth researches on educational administrators' new roles and responsibilities with more participants, comparing different regions, and also with a focus on how the academic success of students gets affected. Moreover, the perspectives of different stakeholders could be integrated so as to further document the situation in detail. And finally, with regards to practice, partnerships and collaborations with administrators and other stakeholders should be strengthened through meetings and assemblies. This surely will lead to sharing different experiences and 
learning from each other, which could yield beneficial results in the end.

\section{References}

Akbaba-Altun, S. (2004). Information technology classrooms and elementary school principles' roles: Turkish experience. Education and Information Technologies. 9(3): 255-270

Akbaba-Altun, S. (2008). Okul yöneticilerinin teknolojiye karş1 tutumlarının incelenmesi. Çă̆daş Eğitim Dergisi. 286(1). 8-14

Akbaba-Altun, S. (2011). Türkiye'nin bir gerçeği olarak deprem: Deprem yaşayan okul müdürlerinin yaşantıları ve depreme ilişkin öneriler. Ankara: Maya Akademi

Akbaba-Altun, S. (2016). Okullarda kriz ve afetlerle başetmede uyarlanabilir liderlik. ss. 351-375. Ö. Erdur Baker ve T. Doğan, Afetler, Krizler, Travmalar ve Psikolojik Yardım (ikinci baskı). Türk Psikolojik Danışma ve Rehberlik Derneği Yayını. Ankara.

Aksoy, H.H., \& Aksoy, N. (2003). Okullarda krize müdahale planlaması. Ankara Üniveristesi, Eğitim Bilimleri Fakültesi Dergisi, 36 1-2

Aksöz, I., Erdur-Baker, Ö., \& Akbaba-Altun, S. (2008). Crisis management strategies by Turkish school principles following natural disasters. In Proc. WCCI 13th. World Conference in Education (pp. 66-80).

Anderson, J. B. (2008). Principals' role and public primary schools' effectiveness in four Latin American cities. The Elementary School Journal, 109(1), 36-60.

Asio, J. M. R., \& Bayucca, S. (2021). Spearheading education during the COVID-19 rife: Administrators' level of digital competence and 
schools' readiness on distance learning. Journal of Pedagogical Sociology and Psychology, 3(1), 19-26.

Behbahani, A. (2011). Educational leaders and role of education on the efficiency of school principals. Procedia-Social and Behavioral Sciences, 15, 9-11.

Berg, B.L., (1998). Qualitative research methods for the social sciences, Needham Heights, MA, Allyn and Bacon.

Blume, F. L., Diehl, R. W., Norton, J. A., Varner, G. F., \& Marshall, J. E. (1946). Duties and responsibilities of high-school principals and assistant principals. The bulletin of the National Association of Secondary School Principals, 30(142), 9-12.

Bortree, D.S. (2010) Exploring adolescent-organization relationships: A study of effective relationship strategies with adolescent volunteers. Journal of Public Relations Research, 22:1, 1-25, DOI: $10.1080 / 10627260902949421$

Canese, V., \& Amarilla, J. (2020). Educational administrators' facing COVID-19 measures in Paraguay. Journal of Educational Technology Development and Exchange (JETDE), 13(1), 4.

Chan, A. K., Nickson, C. P., Rudolph, J. W., Lee, A., \& Joynt, G. M. (2020). Social media for rapid knowledge dissemination: early experience from the COVID-19 pandemic. Anaesthesia, 75, 1579-1582

Çiçek, A., \& Özsezer, S. (2015). Liselerde okul yöneticilerinin kriz yönetme becerileri. The Journal of Academic Social Science Studies, 34, 1-14.

Cisler, A., \& Bruce, M. A. (2013). Principals: What are their roles and responsibilities? Journal of School Counseling, 11(10), n10.

Cosner, S. (2011). Supporting the initiation and early development of evidence-based grade-level collaboration in urban elementary 
schools: Key roles and strategies of principals and literacy coordinators. Urban Education, 46(4), 786-827.

Döş, I., \& Cömert, M. (2012). Öğretmen denetiminde çoklu zekâ kuram1. Turkish Journal of Education, 1(1), 38-51.

Elger, T. (2010), Critical realism, in A. Mills, G. Durepos and E. Wiebe (eds), Encyclopedia of Case Study Research, Thousand Oaks, CA: Sage Publications, vol. 1, pp. 253-257.

Francisco, C.DC., \& Nuqui, A.V. (2020). Emergence of a situational leadership during COVID-19 pandemic called new normal leadership. International Journal of Academic Multidisciplinary Research, 4 (10), 15-19. http://dx.doi.org/10.17613/etsv-nn43

Gardiner, M. E., \& Enomoto, E. K. (2006). Urban school principals and their role as multicultural leaders. Urban Education, 41(6), 560584.

George, C. (1972) The history of management thought. New Jersey: Prentice-Hall, Englewood Cliffs.

Graham, J. W., (2000). Promoting civic virtue organizational citizenship behavior: Contemporary questions rooted in classical quandaries from political philosophy. Human Resource Management Review, Vol.10, Iss.1, s.71-72.

Grant, J. M., \& Mack, D. A. (2004). Preparing for the Battle. Organizational Dynamics, 4(33), 409-425.

Greenhow, C., Lewin, C., \& Staudt Willet, K. B. (2021). The educational response to Covid-19 across two countries: A critical examination of initial digital pedagogy adoption. Technology, Pedagogy and Education, 1-19. 
Hadjithoma-Garstka, C. (2011). The role of the principal's leadership style in the implementation of ICT policy. British journal of educational technology, 42(2), 311-326.

Hayashi, C., \& Soo, A. (2012). Adaptive leadership in times of crisis. Prism, 4(1), 78-86.

Hoerr, T. R. (2009). Principal as parachute. Educational Leadership 90-91

Jimerson, S. R., Brock, S. E., \& Pletcher, S. W. (2005). An integrated model of school crisis preparedness and intervention: A shared foundation to facilitate international crisis intervention. School Psychology International, 26(3), 275-296.

Johnson, N., Veletsianos, G., \& Seaman, J. (2020). US faculty and administrators' experiences and approaches in the early weeks of the COVID-19 pandemic. Online Learning, 24(2), 6-21.

Kadji-Beltran, C., Zachariou, A., \& Stevenson, R. B. (2013). Leading sustainable schools: Exploring the role of primary school principals. Environmental education research, 19(3), 303-323.

Kaminskienè, L., Tūtlys, V., Gedvilienė, G., \& Chu, L. Y. (2021). Coping with the pandemic and the school lockdowns: The perspective of Lithuanian school principals. Journal of Contemporary Educational Studies/Sodobna Pedagogika, 72.

Kells, L. M. (2021). Educational Administrators' Decision-Making Experiences during COVID-19 Pandemic: A Phenomenological Study (Doctoral dissertation, University of La Verne).

Kidson, P., Lipscombe, K. \& Tindall-Ford, S. (2020). Co-designing educational policy: Professional voice and policy making postCOVID. International Studies in Educational Administration, 48 (3), 15-22. 
Kindred, L. W. (1951). What is the principal's responsibility for supervision? The bulletin of the National Association of Secondary School Principals, 35(178), 15-18.

Kwan, P. (2011). Examining the mediating effect of job satisfaction on the relation between responsibilities and career aspiration of vice-principals. International Journal of Educational Research, 50(5-6), 349-361.

Larsen, C., \& Rieckhoff, B. S. (2014). Distributed leadership: Principals describe shared roles in a PDS. International Journal of Leadership in Education, 17(3), 304-326.

Lindberg, E. (2012). The power of role design: Balancing the principals' financial responsibility with the implications of stress. Educational Assessment, Evaluation and Accountability, 24(2), 151171.

Louis, K. S., \& Wahlstrom, K. (2011). Principals as cultural leaders. Phi Delta Kappan, 92(5), 52-56.

Marzano, R. J. (2013). The principal's role in hierarchical evaluation. Educational Leadership 82-83

Mestry, R., Moonsammy-Koopasammy, I., \& Schmidt, M. (2013). The instructional leadership role of primary school principals. Education as Change, 17(sup1), S49-S64.

Mishra, S. K., \& Yadav, B. (2013). Role ability among the middle class principals (Khargone (MP) India). International Journal of Education, 5(1), 156.

Mullen, C. A., \& Hutinger, J. L. (2008). The principal's role in fostering collaborative learning communities through faculty study group development. Theory into practice, 47(4), 276-285.

Oplatka, I. (2013). The principal's role in promoting teachers' extra-role behaviors: Some insights from road-safety education. Leadership and Policy in Schools, 12(4), 420-439. 
Özer, M. (2020). Educational policy actions by the ministry of national education in the times of COVID-19. Kastamonu Education Journal, 28(3), 1124-1129. doi: 10.24106/kefdergi.722280

Pintrich, P. R., \& Schunk, D. H. (2002). Motivation in education: Theory, research, and applications (2nd ed.). New Jersey: Prentice Hall.

Quezada, R. L., Talbot, C., \& Quezada-Parker, K. B. (2020). From bricks and mortar to remote teaching: A teacher education program's response to COVID-19. Journal of Education for Teaching, 46(4), 472-483.

Quilici, S. B., \& Joki, R. (2011). Investigating roles of online school principals. Journal of Research on Technology in Education, 44(2), 141-160.

Reddy, B. V., \& Gupta, A. (2020). Importance of effective communication during COVID-19 infodemic. Journal of Family Medicine and Primary Care, 9(8), 3793.

Reyes-Guerra, D., Maslin-Ostrowski, P., Barakat, M. Y., \& Stefanovic, M. A. (2021). Confronting a Compound Crisis: The School Principal's Role During Initial Phase of the COVID-19 Pandemic. In Frontiers in Education (Vol. 6, p. 87). Frontiers.

Sandoval, J., \& Brock, S. E. (2002). School violence and disasters. Handbook of crisis counseling, intervention, and prevention in the schools, 249-272.

Spillane, J. P., \& Lee, L. C. (2014). Novice school principals' sense of ultimate responsibility: Problems of practice in transitioning to the principal's office. Educational Administration Quarterly, 50(3), 431-465.

Stake, R. E. (1995). The art of case study research. California: Sage. 
Telem, M. (2001). Computerization of school administration: impact on the principal's role - a case study. Computers \& Education, 37(34), 345-362.

Watkins, P. (2005). The principal's role in attracting, retaining, and developing new teachers: Three strategies for collaboration and support. The Clearing House: A Journal of Educational Strategies, Issues and Ideas, 79(2), 83-87.

Wegenke, G. L. (2000). Principal's role in school restructuring in the Des Moines public schools. Education and Urban Society, 32(4), 519-534.

White-Smith, K. A., \& White, M. A. (2009). High school reform implementation: Principals' perceptions on their leadership role. Urban Education, 44(3), 259-279.

Xaba, M. I., \& Nhlapo, V. A. (2014). Principals' views on challenges of their school governance roles. Africa Education Review, 11(3), 424-444.

Xue, E., Li, J., Li, T., \& Shang, W. (2021). China's education response to COVID-19: A perspective of policy analysis. Educational Philosophy and Theory, 53(9), 881-893.

Yin, R. K. (1994). Discovering the future of the case study. Method in evaluation research. Evaluation practice, 15(3), 283-290.

Zincirli, M. (2021). School administrators' views on distance education during the COVID-19 pandemic process. Malaysian Online Journal of Educational Technology, 9(2), 52-66. 


\begin{abstract}
About the authors:
Sadegül Akbaba Altun is a professor at Faculty of Education, Başkent University. She received her Ph.D. degrees from Ankara University and University of Cincinnati. Her research interests include educational administration and leadership, chaos, crisis management and educational technology.
\end{abstract}

Authorship credit details: Conceptualization, administration, methodology; formulated research goals, aims, administrated the research and designed the methodology.

E-mail: akbabas@baskent.edu.tr

Mustafa Bulut is an instructor at School of Foreign Languages, Başkent University. He received his MA degree from Hacettepe University. His research interests include educational administration and leadership, quality assurance and higher education.

Authorship credit details: Writing, review, original draft preparation; preparation, translation of the work.

E-mail: bulutm@baskent.edu.tr 